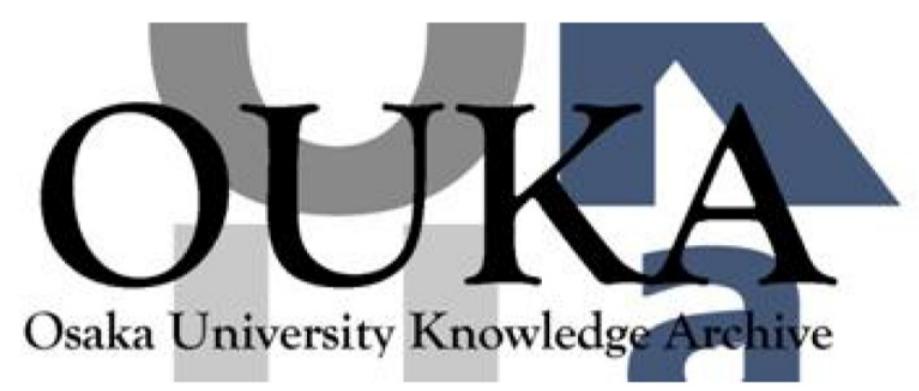

\begin{tabular}{|c|l|}
\hline Title & 耐熱CVケーブル並びに接続部の開発 \\
\hline Author (s) & 山田，浩之; 三宅，孝士郎；村田，義直 他 \\
\hline Citation & 電気材料技術雑誌. 13 p. 54-p. 63 \\
\hline Issue Date & $2004-09-25$ \\
\hline oaire:version & VoR \\
\hline URL & https://hdl. handle. net/11094/76779 \\
\hline rights & \\
\hline Note & \\
\hline
\end{tabular}

Osaka University Knowledge Archive : OUKA

https://ir. Library. osaka-u. ac. jp/

Osaka University 


\title{
耐熱CVケーブル並びに接続部の開発
}

\author{
山田 浩之、三宅 孝士郎 \\ 関西電力侏) 電力技術研究所 電力基盤技術研究室（流通） \\ 干 661-0974 兵庫県尼崎市若王寺3-11-20 \\ 村田＼cjkstart義直*、岸 幸治*、渡辺 傑** \\ *:株ジェイ・パワーシステムズ 研究開発センター システムグループ \\ テ319-1414 茨城県日立市日高町5-1-1 \\ **:(森ジェイ・パワーシステムズ 電力事業部 西部技術グループ \\ 干554-0024 大阪府大阪市此花区島屋1-1-3
}

\section{Development of Heat-resistant XLPE Cable and Accessories}

\author{
Hiroyuki YAMADA, Koujirou MIYAKE \\ The Kansai Electric Power Co., Inc., \\ 11-20 Nakoji, 3-Chome, Amagasaki, Hyogo-ken, 661-0974, Japan \\ Yoshinao MURATA*, Koji KISHI*, Masaru WATANABE** \\ J-Power Systems Corp. , \\ * : 5-1-1 Hitaka-cho, Hitachi-shi, Ibaraki-ken, 319-1414, Japan \\ ** : 1-1-3 Shimaya, Konohana-ku, Osaka, 554-0024, Japan
}

We have developed heat-resistant XLPE cable and accessories that can be operated at $105^{\circ} \mathrm{C}$ as the maximum permissible conductor temperature in normal operation. Through this cable system, greater transmission capacity can be achieved using existing cable ducts and without increasing the conductor size of the cable. We have developed heat-resistant XLPE insulation material which has a higher melting point than that of conventional XLPE. The breakdown strength of heat-resistant XLPE cable at $105^{\circ} \mathrm{C}$ is almost the same as that of conventional XLPE cable at $90^{\circ} \mathrm{C}$. The heat deformation of the new cable at $105^{\circ} \mathrm{C}$ is almost the same as that of conventional XLPE cable at $90^{\circ} \mathrm{C}$. Conventional self-pressurized rubber joints can be applied to heat-resistant cable lines with the new waterproof joint compound with low heat resistivity.

KEYWORDS : XLPE cable, Self pressurized joint, Heat resistance, Permissible temperature. キーワード：CVケーブル，自己収縮型接続部，耐熱性、許容温度

1.はじめに

近年、既存設備を利用してケーブル線路の送 電容量を増大することが望まれつつある。これ は、日本国内においては、管路布設が多く採用 されているが、管路の建設はケーブル線路建設
費に比ベコスト高であり、また、特に都心部で は、管路建設による新規送電ルートの構築は難 しい状況となっているためである。

既設管路を利用して送電容量増大を図る場合 は、ケーブル許容温度を高めて、同一導体サイ 
ズで大容量送電を可能とすることが有効であ る。そこで、筆者らは、現行の架橋ポリエチレ ン電力ケーブル (以下、CVケーブル) の常時 許容温度 $90^{\circ} \mathrm{C}$ を $105^{\circ} \mathrm{C}$ 高めることを目標とし た、耐熱 CVケーブル並びに接続部を開発した。 本稿では、開発した耐熱 C V ケーブル並びに接 続部の開発ポイントと諸特性について報告する。

\section{2. 開発目標と開発ポイント}

\section{1. 開発目標温度の設定}

現行 C V ケーブルの常時許容温度および短時 間許容温度は、それぞれ $90^{\circ} \mathrm{C} 、 105^{\circ} \mathrm{C}$ である。こ れらの許容温度を高めることで、同一導体サイ ズでの送電容量を増大することが可能である。

しかしながら、常時許容温度を無制限に高く 設定すると、例えば土壌の乾燥などの周囲環境 への影響が懸念される。また、過度の高温運転 は、ケーブルの伸び出し等を考慮したオフセッ 卜設計を大幅に見直す必要が生じ、設備全体と してはかえってコスト増となる可能性がある。

上記のことも考慮しつつ、常時許容温度を高 めることによって、現行 C V ケーブに対して 1 ランク小さな導体サイズで同量の送電容量を確 保できるような、開発目標温度を検討した。検 討結果の一例として、単心ケーブルを管路に布

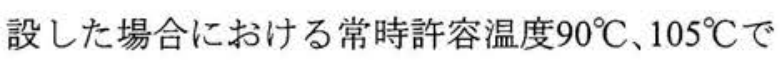
の導体サイズと送電容量の関係を図 1 に示す。 常時許容温度を $105^{\circ} \mathrm{C} に$ 高めることによって、約 $10 \%$ の送電容量増大が可能であり、1000 $\mathrm{mm}^{2}$ 以上 の大サイズケーブルにおいて 1 ランク 小さな導

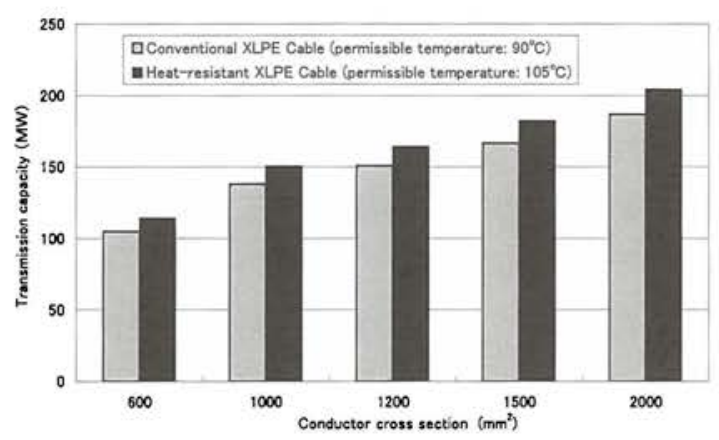

図1 導体サイズと送電容量の関係

Fig. 1. Relationship between conductor cross section area and transmission capacity
体サイズでほぼ同量の送電容量を確保すること ができる。従って、本研究においては、常時許 容温度を $105^{\circ} \mathrm{C}$ とることを目標とした。

次に、短時間許容温度の目標設定について以 下に述べる。現行 C V ケーブルでは、常時許容 電流の $110 \%$ 過負荷電流を許容できる温度と して、短時間許容温度 $105^{\circ} \mathrm{C}$ が設定されている。 耐熱 C Vケーブルにおいても同様に、常時許容 温度を $105^{\circ} \mathrm{C}$ とた場合の常時許容電流に対し て、その $110 \%$ の電流を許容できる温度を短時間 許容温度とすることとし、本研究では、短時間 許容温度を $125^{\circ} \mathrm{C}$ とすることを目標とした。

\section{2. ケーブルの熱的制約と開発ポイント}

近年、送電設備の増強コストを極力抑えるこ とを目的として、現行 CVケーブルの使用限界 に関する研究が各所で実施されている(1)(2)(3)(4)。 これら研究のなかで、現行 C V ケーブルの使用 温度に関して、以下のような報告がなされている。

・ C Vケーブルの初期絶縁破壊強度は、温度 上昇に伴い低下するものの、 $90 \sim 120^{\circ} \mathrm{C}$ 高 温領域でも高い值である ${ }^{(1)}$ 。

・ C V ケーブルは絶縁体の融点 (約 $\left.105^{\circ} \mathrm{C}\right)$ 以 上では、絶縁破壊までの時間が短くなり、 長期電気特性に課題がある ${ }^{(3)}$ 。

- C V ケーブルの加熱変形率は、絶縁体融点 以上になると急増する ${ }^{(3)}$ 。

これらの結果は、CVケーブルが、融点以上 の温度での連続使用に課題があることを示唆し ている。また、クリート等によるケーブル把持 部を考えると、実運用中はケーブル温度を融点 以下に抑えることが望ましい。このことから、 耐熱 C Vケーブルの開発では、現行架橋ポリエ チレン (XLPE: Cross-linked Polyethylene) 絶縁 材料よりも高い融点を有する C V ケーブル用材 料の開発が重要なポイントとなる。

\section{3. 接続部の開発ポイント}

近年、実線路に適用される接続部としては、 コンパクト化、施工時間の短縮化、スキルレス 化などの利点を有する、自己収縮型のワンピー 
ス型接続部（S P J : Self-Pressurized Joint）が 主流となりつつある ${ }^{(5)}$ 。耐熱 C V ケーブル用接 続部としても、同様のメリットが要求されるこ とから、本研究では、耐熱 C V ケーブル用 S P Jの開発を目指すこととした。

現行 S P J は常時許容温度 $90^{\circ} \mathrm{C} て ゙ の$ 使用を目 的に設計がなされたものであり、更なる高温使 用に対する検討はなされていない。そこで、現 行 S P J の諸特性を見直しながら、耐熱C V ケ ーブル用としての検討を実施し、必要であれば 改善を施すこととした。

\section{3. 耐熱 CVケーブルの開発}

\section{1. 耐熱 $\mathrm{V} \vee$ ケーブル用絶縁体の開発}

耐熱 C Vケーブル用絶縁材料（X L P E）を 開発するために、種々の高融点ポリエチレン $(\mathrm{P}$ E) 材料について熱機械特性、電気特性、加工 性の面から検討を実施し、非架橋時の融点が $128^{\circ} \mathrm{C}$ の高融点 P E を選定した ${ }^{(6)}$ 。高融点 P E は、ケーブル押出加工時の温度を高温に設定す る必要があり、押出時の架橋反応を防止するた めに、現行の架橋剂（DC P）よりも半減期が 長い有機過酸化物を用いることとした。

図 2 に耐熱 CV ケーブル用として選定したX L P E 材料のD S C 特性を現行 X L P E 材料と 比較して示す。一般にP E 材料を架橋すると融 点が低くなる傾向にあるが、耐熱X L P E の融 点はD S C ピーク温度で $123^{\circ} \mathrm{C}$ と評価され、現行 $\mathrm{X} L \mathrm{P}$ Eよりも $20^{\circ} \mathrm{C}$ 高い融点を有している。

図 3 は、耐熱X L P E 材料の加熱変形率の温 度依存性を示したものである。耐熱X L P E の 加熱変形率は、同一温度では現行X L P E に比 べ耐熱X L P E の方が変形率が小さくなってお り、耐熱X L P E $105^{\circ} \mathrm{C}, 125^{\circ} \mathrm{C}$ での加熱変形率 は、現行X L P E $990^{\circ} \mathrm{C}, 105^{\circ} \mathrm{C}$ とほぼ同等とな っている。

さらに、図 4 に示す耐熱X L P E 材料の熱膨 張率の温度依存性も耐熱X L P E の $105^{\circ} \mathrm{C}$ 、 $120^{\circ} \mathrm{C}$ での值が、現行X L P E $90^{\circ} \mathrm{C} 、 105^{\circ} \mathrm{C}$ で の值とほぼ同等の值となっている。

以上の結果から、耐熱X L P E 材料は、 $105^{\circ} \mathrm{C}$ 、

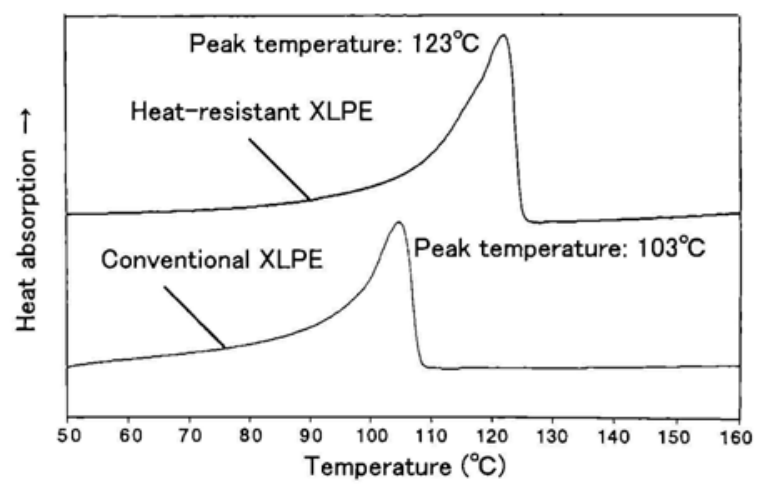

図2 耐熱X L P E と現行X L P EのD S C曲線

Fig. 2.DSC curve of heat-resistant XLPE and conventional XLPE

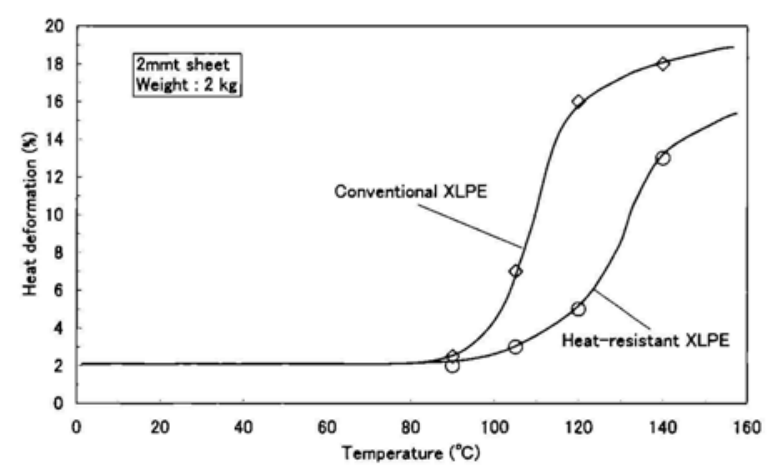

図3 加熱変形率の温度依存性

Fig.3. Temperature dependence of heat deformation

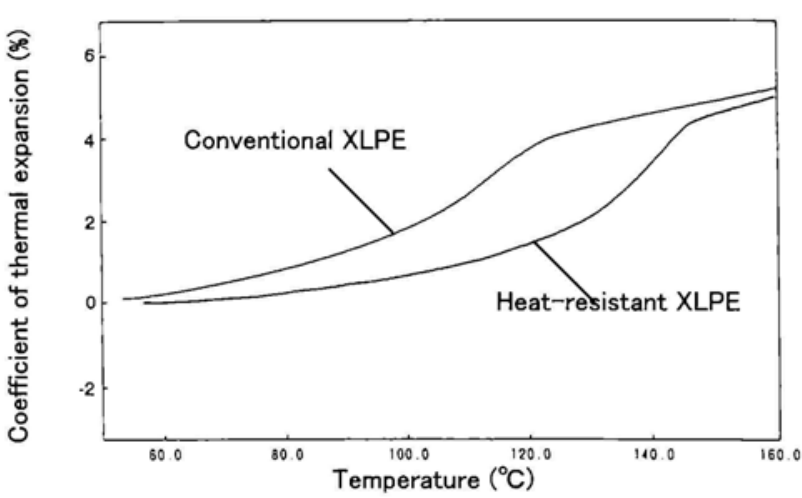

図4 熱膨張率の温度依存性

Fig.4. Temperature dependence of coefficient of thermal expansion

$125^{\circ} \mathrm{C}$ において現行 C Vケーブルの $90 、 105^{\circ} \mathrm{C}$ と 同等の熱挙動特性が期待できる。このことは耐 熱 CV ケーブルに対し、現行のクリート等がそ のまま使えることを示唆しており、また、ケー ブルの構造設計やオフセット等のケーブル布設 設計を大幅に見直す必要がないことを示唆する ものである。

一方、ケーブル絶縁材料としては、設計寿命 
30 年に亘って十分な熱老化特性を有する必要が ある。そこで、連続 $105^{\circ} \mathrm{C}$ 使用に耐える熱老化 特性を得るために、酸化防止剤の種類・添加量 を検討した。開発した耐熱X L P E 絶縁体にお いて、伸びの絶対值が $50 \%$ に低下するまでの時 間を寿命として評価した熱老化特性のアレニウ スプロットを図 5 に示す。本結果から、105으 の30年使用に十分耐える熱老化特性を有してい ることが示唆される。なお、耐熱X L P E 絶縁 体の開発では、図 5 に示した熱老化特性を得る こと以外にも、酸化防止剤の及ぼす誘電正接等 の電気特性への影響も考慮し最終配合を決定し た。

耐熱X L P E 材料の電気特性については、シ 一ト試料において交流電気トリー開始特性につ いて評価を実施し、良好な特性を得ている( ${ }^{(6)}$ 。 しかし、ケーブルの破壊特性は、製造条件等が 影響して、シートで得られた特性と必ずしも一 致しない場合がある。従って、最終的にはケー ブルでの評価を実施することとした。なお、内 外半導電層用材料ならびにシース材料について も同様の検討を実施し、特性上の問題がないこ とを確認した。

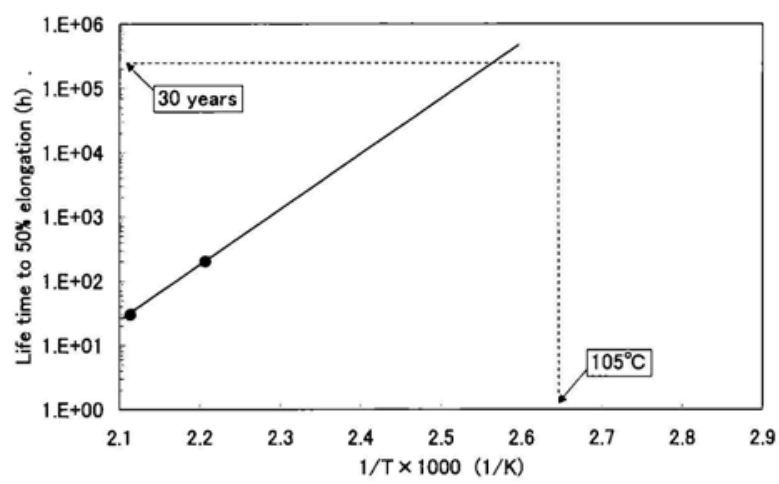

図5 熱老化特性のアレニウスプロット Fig.5.Arrehnius plots of thermal degradation

\section{2. モデルケーブルによる性能評価}

開発した耐熱 C V ケーブル用材料を使用した モデルケーブルを試作した。表 1 はモデルケー ブルの構造であり、絶縁厚さは6mm、導体サイズ は100m²とした。

図 6 は、モデルケーブルの A C 並びに雷イン パルス（Imp）絶縁破壊強度の温度依存性を示
したものである。A C 絶縁破壊強度は温度にほ とんど依存しない。一方、Imp 絶縁破壊強度は 温度上昇に伴って若干低下する傾向にある。常 温と $105^{\circ} \mathrm{C}$ における破壊電圧値の比は、A C と Imp でそれぞれ、1.0，1.14と見積もられる。

表1 モデルケーブルの構造

Table 1. Construction of model cable

\begin{tabular}{|c|c|c|c|}
\hline \multirow{2}{*}{ Conductor } & Cross section & $\mathrm{mm}^{2}$ & 100 \\
\cline { 2 - 4 } & Outer diameter & $\mathrm{mm}$ & 12.0 \\
\hline \multicolumn{2}{|c|}{ Thickness of conductor screen } & $\mathrm{mm}$ & 1.0 \\
\hline $\begin{array}{c}\text { Insulation } \\
\text { Heat-resistant } \\
\text { XLPE }\end{array}$ & Thickness & $\mathrm{mm}$ & 6.0 \\
\cline { 2 - 4 } & Outer diameter & $\mathrm{mm}$ & 26.0 \\
\hline \multicolumn{2}{|c|}{ Thickness of insulation screen } & $\mathrm{mm}$ & 1.0 \\
\hline
\end{tabular}

$\mathrm{A} C$ 電圧に対する温度係数は、現行 C V ケー ブルの值に比べると小さい值である。現行 C V ケーブルでは、アセトフェノン等の架橋剤分解 残渣が、常温 $60^{\circ} \mathrm{C}$ 程度の低温域では高電界部 分に顕著に凝集し電界緩和効果を発揮するが、 $90^{\circ} \mathrm{C}$ 程度の高温域ではこの凝集濃度が低下する ために電界緩和効果も弱まり、A C 破壊強度の 温度依存性が出現すると考えられている(1)。一 方、耐熱 C V ケーブルに適用した架橋剤は、電 界緩和効果を発揮する残渣成分がないために、 現行 C V ケーブルに比べ温度依存性が小さくな ったと考えられる。Imp 破壊強度に対してはア セトフェノン等の残渣が影響しないことから、 現行 C V ケーブルと同様な温度依存性が出現し たものと考えられる。

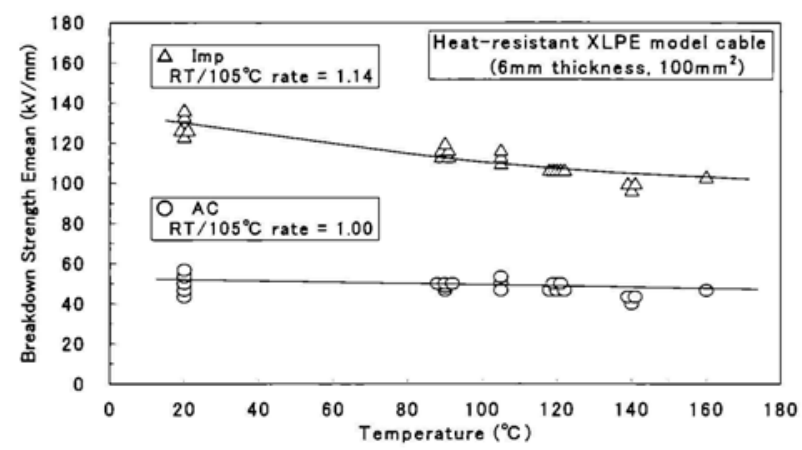

図6 絶縁破壊強度の温度依存性

Fig.6. Temperature dependence of breakdown strength 


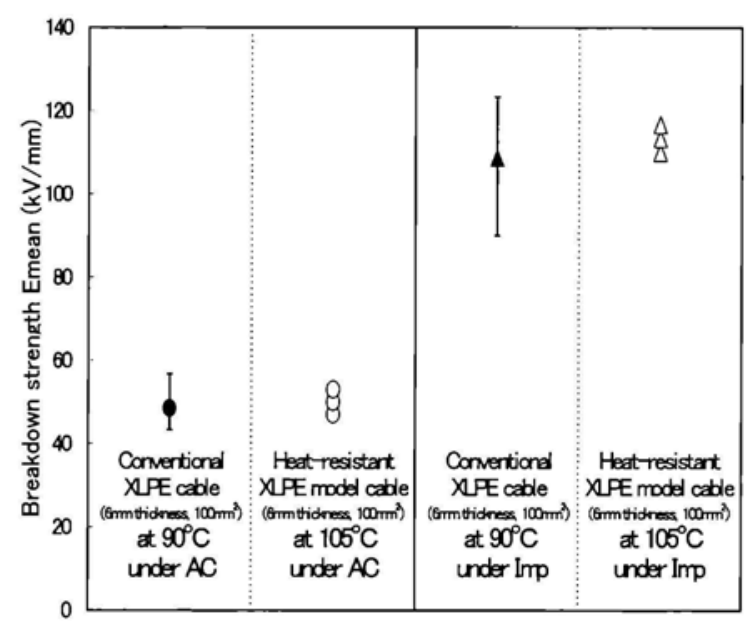

図7 耐熱CVケーブルと現行CVケーブルの 初期絶縁破壊強度の比較

Fig.7. Initial breakdown strength of heat-resistant XLPE model cable and conventional XLPE cable

図 7 は、耐熱 $\mathrm{CV}$ ケーブルの $105^{\circ} \mathrm{C}$ における絶 縁破壊強度を現行 C V ケーブルの $90^{\circ} \mathrm{C}$ における 絶縁破壊強度 ${ }^{(1)}$ と比較したものである。耐熱 C $\mathrm{V}$ ケーブルの $105^{\circ} \mathrm{C} に お け る$ 絶縁破壊強度は、現 行 C Vケーブルの $90^{\circ} \mathrm{C}$ と同等の良好な值を有し ている。

耐熱X L P E の長期特性を評価するために、 モデルケーブルを用いて、連続 $105^{\circ} \mathrm{C}$ 下でのV V $\mathrm{t}$ 試験を実施した。

供試ケーブルの加熱保持は、ヒーターによる 外部均一加熱とした。図 8 に試験結果を示す。 モデルケーブルの連続高温 $\left(105^{\circ} \mathrm{C}\right)$ 下での寿命 指数として $\mathrm{n}=16$ が見積もられ、現行 C Vケー ブルの絶縁設計に用いられている寿命指数（n =15)の採用が十分可能なことを示唆している。

以上述べたように、試作したモデルケーブル は、高温領域においても、十分な初期および長

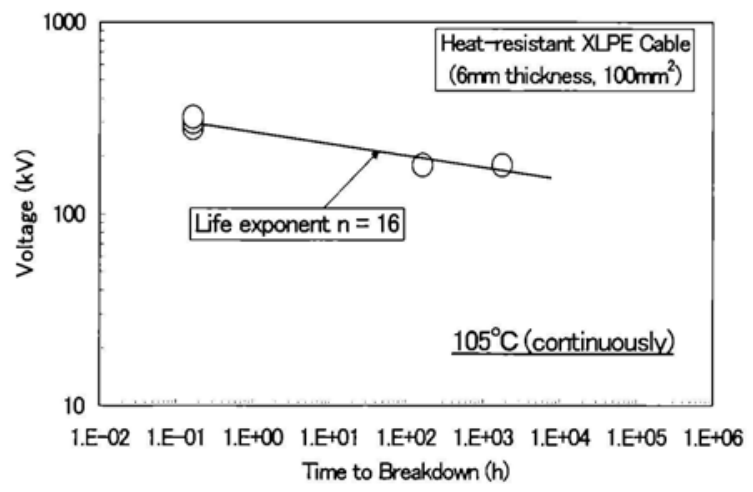

図8 耐熱 C Vモデルケーブルの $\mathrm{V}-\mathrm{t}$ 特性 Fig.8. V-t characteristics of heat-resistant XLPE cable
期特性を有していることが判明した。

\section{4. 接続部の開発}

\section{1. 現行 $S P J の$ 熱的制約}

現行 S P J は、常時許容温度 $90^{\circ} \mathrm{C}$ の C V ケー ブルに対して設計されたものである。ここでは、 現行 S P J を耐熱C V ケーブル用接続部として 適用する場合の課題について検討した。

S P J に適用している非結晶性のエチレンプ ロピレンゴム（E P R）は、絶縁破壊強度の温 度依存性が小さい(7) と考えられることから、S P J の熱的制約としては、特に、熱劣化特性と 応力緩和特性が挙げられる ${ }^{(5)}$ 。

図 9 は、伸びの絶対值が100\%に低下するまで の時間を寿命として評価した場合の S P J 絶縁 ゴム材料における熱老化特性のアレニウスプロ ットである。この結果から、S P J 絶縁ゴムは $100^{\circ} \mathrm{C}$ で 30 年の熱老化寿命を有していると推定 される。

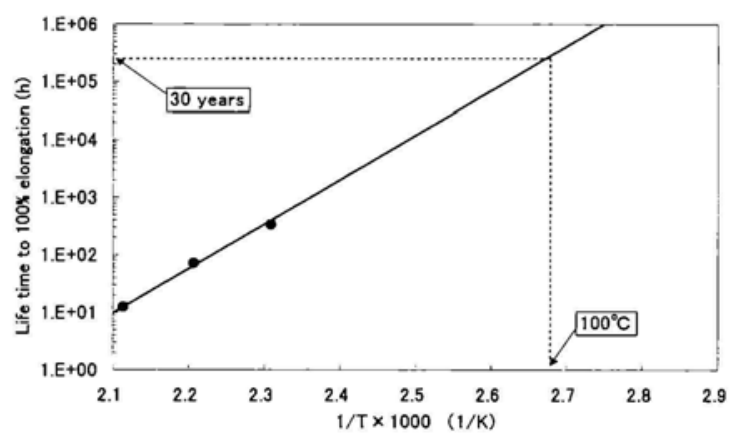

図9 S P J ゴム絶縁材料の熱劣化特性の アレニウスプロット

Fig.9. Arrehnius plots of rubber insulation of SPJ

一方、S P J では、実使用 30 年に亘って安定 した電気性能を維持するために、ケーブル絶縁体 との界面の面圧を $0.2 \mathrm{MPa}$ 以上に保つ必要があり、 ゴム材料の応力緩和特性は重要な要素である。

図10に実機 S P J の拡径率と同程度の $30 \%$ 伸 びで評価した絶縁ゴム材料、導電性ゴム材料の シートサンプルの $100^{\circ} \mathrm{C}$ での応力緩和特性を示 す。なお、図10の白抜きプロットは $100^{\circ} \mathrm{C} て ゙ の$ 実 測データであり、黒塗りプロットはW L F 式 ${ }^{(8)}$ を用いて換算して得られたデータである。W L $\mathrm{F}$ 式による換算は、 $120^{\circ} \mathrm{C} 、 130^{\circ} \mathrm{C} 、 140^{\circ} \mathrm{C}$ で得た 


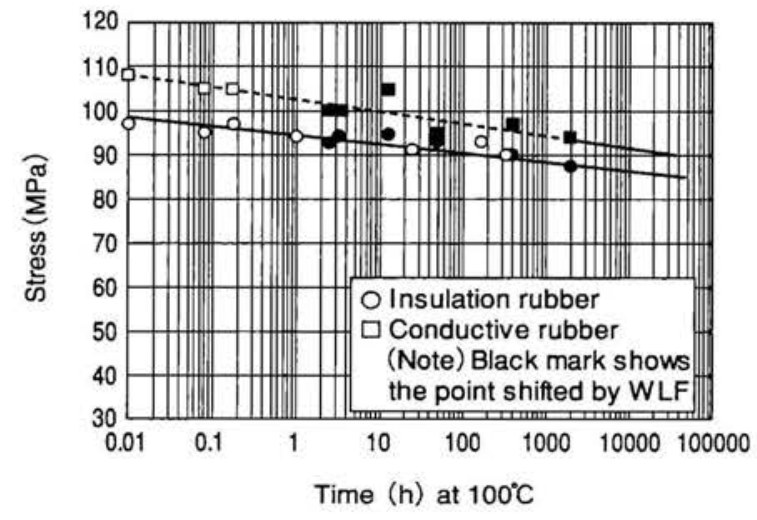

図10 S P J ゴム材料の応力緩和特性(30\%伸び)

Fig. 10. Stress relief characteristics of the rubber(at $30 \%$ strain)

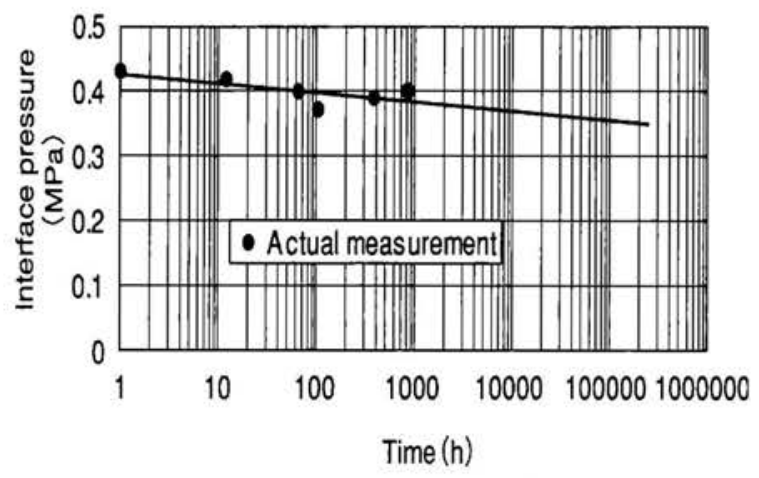

図11 S P J 面圧実測結果

Fig. 11. Actual measurements of the interface pressure of SPJ

データをそれぞれ-0.403，-0.578，-0.739のシフ

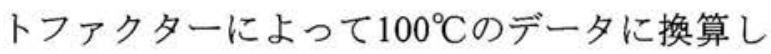
た。図10から、時間経過とともに応力は徐々に 低下するものの、30年後における初期值からの 応力低下の割合は $15 ２ 0 \%$ と見積もられる。ま

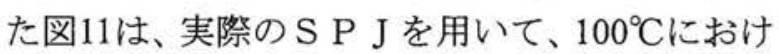
る界面面圧を実測した結果である。実際の S P $\mathrm{J}$ を用いて評価した面圧低下特性は、図10に示 したシートサンプルによる応力緩和特性と類似 した結果となっている。ところで、一般に高分 子材料の応力緩和は分子主鎖のミクロブラウン 運動の緩和に起因するような物理変化によるも のと熱酸化劣化による分子鎖切断のような化学 変化によるものが考えられる ${ }^{(9)}$ が、図 9 に示し た熱劣化特性と考え併せると、 $100^{\circ} \mathrm{C} \cdot 30$ 年の領 域においては物理変化に起因する緩和が主であ ると考えられる。このことから、図10、図11で は、103時間オーダーのデータから実運用30年 (105時間オーダー)まで直線で外挿して評価が 可能であると考えた。
図10、図11の結果は、S P J の設計寿命30年 に対して、界面面圧の初期設定值は、面圧低下 率として $20 \%$ 考慮すれば十分であることを示 唆している。

\section{2. 実線路運転状況下における \\ SP J温度解析評価}

耐熱 CVケーブルに適用した場合の S P J 温 度を、図12に示す構造に対して解析評価した。 温度解析は有限要素法により実施し、周囲温度 は $40^{\circ} \mathrm{C}$ とした。

表 2 に各種ケーブル布設条件におけるS P J の温度解析結果を示す。ケーブルが管路布設の 場合は、S P J 温度は $75^{\circ} \mathrm{C}$ 見積もられ、 $105^{\circ} \mathrm{C}$ のケーブル運転条件下において、現行 S P J が そのまま適用できることが判明した。

$77 \mathrm{kV} ・ 1 \times 2000 \mathrm{~mm}^{2}$ 耐熱 C V ケーブルを洞道に 3 条俵積布設した場合と $77 \mathrm{kV} \cdot 3 \times 600 \mathrm{~mm}^{2}$ トリプ レックスケーブルを洞道布設した場合では、S $\mathrm{P} \mathrm{J}$ 温度は約 $100^{\circ} \mathrm{C}$ と見積もられた。この結果 は、材料特性からは許容できる範囲であるもの の、実運用上は裕度をもたせるために、S P J 温度上昇を $5 \sim 10^{\circ} \mathrm{C}$ 低減させる対策が望まれる。

S P J 温度上昇を低減させる手法としては、 局部的な水冷や風冷といった手法が考えられる が、本開発では、設備コストの面で有利な、低 熱抵抗防水コンパウンドの適用を検討した。沉 用の防水コンパウンド（熱抵抗率 $: 4.7 \mathrm{~K} \cdot \mathrm{m} / \mathrm{W}$ ) の代わりに低熱抵抗防水コンパウンド(熱抵抗 率 $1 \mathrm{~K} \cdot \mathrm{m} / \mathrm{W})$ を適用した場合の温度解析結果を 表 2 に示した。本結果から、低熱抵抗防水コン パウンドの適用により、S P J 部温度上昇を 5 $\sim 10^{\circ} \mathrm{C}$ 低减できることが期待できる。

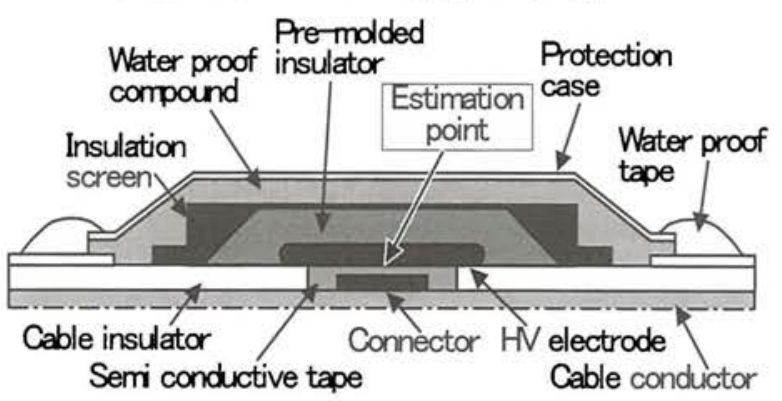

図12 温度シミュレーションモデル

Fig. 12. Simulation model 
表 2 温度シミュレーション条件および結果

Table 2.Simulation condition and results

\begin{tabular}{|l|l|l|l|}
\hline Cable & $77 \mathrm{kV} 1 \times 1000 \mathrm{~mm}^{2}$ & $77 \mathrm{kV} 1 \times 2000 \mathrm{~mm}^{2}$ & $77 \mathrm{kV} 3 \times 600 \mathrm{~mm}^{2}$ \\
\hline Joint & SPJ & SPJ & SPJ \\
\hline Cable laying condition & Cable duct pipe & Cable tunnel & Cable tunnel \\
\hline Cable laying formation & 1 or 3 cables in a duct & Trefoil formation & Triplex type cable \\
\hline Joint position & In manhole & In cable tunnel & In cable tunnel \\
\hline $\begin{array}{l}\text { Cable conductor temperature } \\
\text { (assumed maximum permissible temperature for normal } \\
\text { operation) }\end{array}$ & $105^{\circ} \mathrm{C}$ & $105^{\circ} \mathrm{C}$ & $105^{\circ} \mathrm{C}$ \\
\hline $\begin{array}{l}\text { Maximum temperature of SPJ } \\
\text { In case of conventional water proof compound using }\end{array}$ & $75^{\circ} \mathrm{C}$ & $98^{\circ} \mathrm{C}$ & $97^{\circ} \mathrm{C}$ \\
\hline $\begin{array}{l}\text { Maximum temperature of SPJ } \\
\text { In case of low heat resistivity water proof compound us- } \\
\text { ing }\end{array}$ & $73^{\circ} \mathrm{C}$ & $93^{\circ} \mathrm{C}$ & $88^{\circ} \mathrm{C}$ \\
\hline
\end{tabular}

\section{5. プロトタイプケーブルによる性能評価}

耐熱 CVケーブル並びに低熱抵抗コンパウン ドを適用した S P J の性能を確認するために、 絶縁厚さ $8.5 \mathrm{~mm}$ 、導体サイズ $600 \mathrm{~mm}^{2}$ の $77 \mathrm{kV}$ 級プロ トタイプケーブルを試作した。表3にプロトタイ プケーブルの構造を示す。なお、供試した S P $\mathrm{J}$ は77kV 実機相当のものである。

表3 77kV 級プロトタイプケーブルの構造 Table 3.Construction of prototype cable

\begin{tabular}{|c|c|c|c|}
\hline \multirow{2}{*}{ Conductor } & Cross-section & $\mathrm{mm}^{2}$ & 600 \\
\cline { 2 - 4 } & Outer diameter & $\mathrm{mm}$ & 29.5 \\
\hline \multicolumn{2}{|c|}{ Thickness of conductor screen } & $\mathrm{mm}$ & 1.0 \\
\hline $\begin{array}{c}\text { Insulation } \\
\text { Heat-resistant } \\
\text { XLPE }\end{array}$ & Thickness & $\mathrm{mm}$ & 8.5 \\
\cline { 2 - 4 } & Outer diameter & $\mathrm{mm}$ & 48.5 \\
\hline \multicolumn{2}{|c|}{ Thickness of insulation screen } & $\mathrm{mm}$ & 1.5 \\
\hline
\end{tabular}

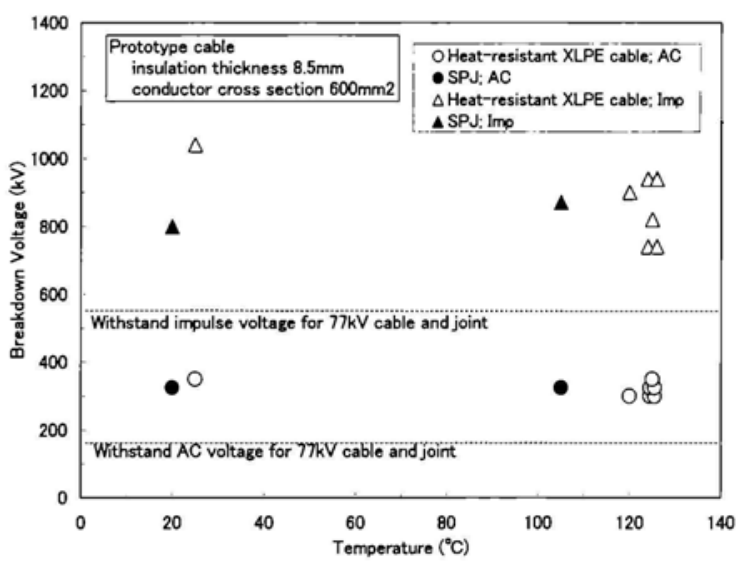

図13 プロトタイプケーブル並びにS P J の初期破壊電圧 Fig. 13.Initial electric breakdown test results of prototype cable and SPJ
プロトタイプケーブル並びに S P J の初期絶 縁破壊試験結果を図13に示す。ここで、白抜き のプロットはケーブルの絶縁破壊電圧を、黒塗 りプロットはS P J の絶縁破壊電圧を示す。図 13に示すように、プロトタイプケーブル並びに S P J は、AC，雷インパルスのいずれにおい ても、77kV 級の耐電圧值を満足し、さらに破壊 電圧は実運用に対して十分な裕度を有している ことが確認された。この結果は、S P J の高温 性能が予想通り常温に比べ低下しないことを示 している。

次に、低熱抵抗防水コンパウンドの効果を確 認するために、S P J の通電下における温度測 定を実施した。実験には、汎用防水コンパウン ドを用いた S P J と、低熱抵抗防水コンパウン ドを用いた S P J をそれぞれ供試した。通電電 流は洞道布設(周囲温度 $40^{\circ} \mathrm{C}$ ) 時の耐熱 $\mathrm{CV}$ 許容 電流、1134A とし、S P J 表面温度を洞道温度 $40^{\circ} \mathrm{C}$ と等価になるように加熱保温した。測定結 果を図14に示す。低熱抵抗防水コンパウンドを 用いた場合の S P J 温度は、解析結果と同様、 汎用防水コンパウンドを用いた場合に比べて約 $10^{\circ} \mathrm{C}$ 低くなり、 $85^{\circ} \mathrm{C}$ に抑えられることが確認さ れた。 


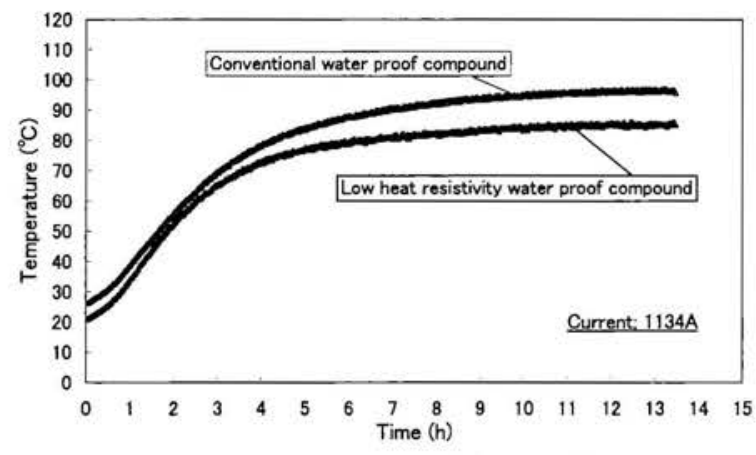

図14 S P J の通電下温度測定結果

Fig. 14. Measurement results of maximum temperature of SPJ

\section{6. 最終性能評価}

\section{1. 耐熱 C Vケーブルの絶縁厚選定}

$77 \mathrm{kV}$ 耐熱 C V ケーブルを製作するにあたり、 これまでの破壊試験結果から絶縁厚さの選定を 行った。

まず、必要絶縁厚さについては、ケーブル単 体および接続箱を考慮した必要絶縁厚さを算出 した。

結果、表4に示す通り、接続箱立上部(ケーブ ル外導処理部)における雷インパルス耐電圧か ら決まる必要絶縁厚が一番大きく、導体サイズ $600 \mathrm{~mm}^{2}$ ケーブルで必要絶縁厚は $9.5 \mathrm{~mm} 、 2000 \mathrm{~mm}^{2}$ ケ ーブルで10m盀とな、現行の $77 \mathrm{kV} \mathrm{C} \mathrm{V} \mathrm{ケーブ}$ ルより $1 \mathrm{~mm}$ 薄くできることが分かった。

しかし、1mm薄くしたとしても、関西電力侏の 標準管路サイズに収めることのできるケーブル 仕様に変化が無く、逆に、現行のCVケーブル に絶縁厚に合わせた方が接続箱の設計並びにク リート寸法等の面で合理的である。

よって、ケーブル絶縁厚は従来仕様に合わせ てトリプレックス形ケーブル $\left(100 \mathrm{~mm}^{2} \sim 400 \mathrm{~mm}^{2}\right)$ で は $10 \mathrm{~mm}$ 、単心ケーブル $\left(600 \mathrm{~mm}^{2} \sim 2000 \mathrm{~mm}^{2}\right)$ では $11 \mathrm{~mm}$ を採用することとした。

表4 必要絶縁厚さの検討

Table 4. Examination of insulated thickness

\begin{tabular}{|c|c|c|c|c|}
\hline \multicolumn{2}{|c|}{ Conductor size } & $2000 \mathrm{sq}$ & $600 \mathrm{sq}$ & $150 \mathrm{sq}$ \\
\hline \multirow{2}{*}{ Cable simple substance } & A C & \multicolumn{3}{c|}{$4.1 \mathrm{~mm}$} \\
\cline { 2 - 5 } & Imp & \multicolumn{3}{c|}{$6.3 \mathrm{~mm}$} \\
\hline \multirow{2}{*}{ Joint Box consideration } & A C & $8.2 \mathrm{~mm}$ & $7.7 \mathrm{~mm}$ & $7.0 \mathrm{~mm}$ \\
\cline { 2 - 5 } & Imp & $9.9 \mathrm{~mm}$ & $9.2 \mathrm{~mm}$ & $8.5 \mathrm{~mm}$ \\
\hline \hline \multirow{2}{*}{$\begin{array}{c}\text { Required insulation thickness } \\
\text { (Up Valuation at } 0.5 \mathrm{~mm} \text { ) }\end{array}$} & $10.0 \mathrm{~mm}$ & $9.5 \mathrm{~mm}$ & $8.5 \mathrm{~mm}$ \\
\hline
\end{tabular}

\section{2. 実規模ケーブルによる性能評価}

本開発の最終検証試験として、現行の77kVC $\mathrm{V}$ ケーブルと同等の絶縁厚さ11mmで製造した $77 \mathrm{kV}$ 耐熱 C V ケーブルと S P J を用い、関西電 力㑣山崎実験センターにおいて、2002年11月か ら1年間にわたる長期課通電試験を実施した。表 5 にケーブルの構造を、図15に試験状況を示す。

表5 77kV 耐熱C V ケーブルの構造

Table 5. Construction of 77kV Heat-resistant XLPE Cable

\begin{tabular}{|c|c|c|c|}
\hline \multirow{2}{*}{ Conductor } & Cross-section & $\mathrm{mm}^{2}$ & 600 \\
\cline { 2 - 4 } & Outer diameter & $\mathrm{mm}$ & 29.5 \\
\hline \multicolumn{2}{|c|}{ Thickness of conductor screen } & $\mathrm{mm}$ & 1.0 \\
\hline $\begin{array}{c}\text { Insulation } \\
\text { Heat-resistant } \\
\text { XLPE }\end{array}$ & Thickness & $\mathrm{mm}$ & 11.0 \\
\cline { 2 - 4 } & Outer diameter & $\mathrm{mm}$ & 68.5 \\
\hline \multicolumn{2}{|c|}{ Thickness of insulation screen } & $\mathrm{mm}$ & 1.5 \\
\hline
\end{tabular}

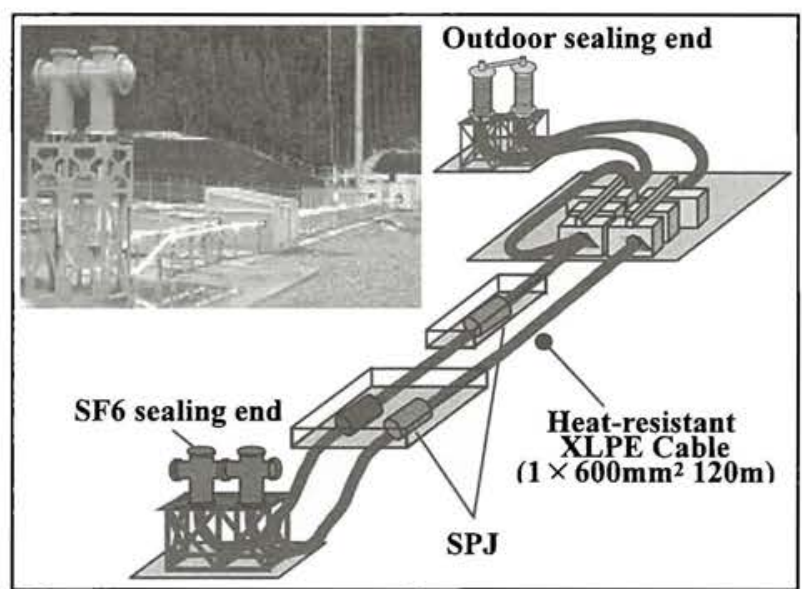

図15 長期課通電試験状況

Fig. 15.View of long-term heating cycle voltage test

試験については、JEC-3408-1997に準拠した試 験を行うとともに、さらに本ケーブル材料が新 規材料であることを加味し、IEC62067の PQ テ ストに準拠した試験も併せて行える方法で実施 した。

課電試験については、課電電圧を $77 \mathrm{kV}$ (1.7U0)、課電期間を 1 年(8760時間)とし、ヒー

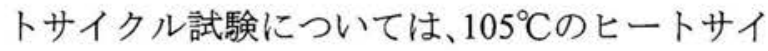
クル $(8$ 時間 $\mathrm{ON} / 16$ 時間 $\mathrm{OFF}$, 導体最高温度 2 時 間以上保持)を 180 回以上、 $125^{\circ} \mathrm{C}$ のヒートサイク ル(8時間 ON $/ 16$ 時間 OFF)を30回以上実施し た。試験条件を表6に示す。 
なお、(1)線路組立後(課通電試験開始前)、(2) $\mathrm{JEC}$ 試験相当完了後 $\left(105^{\circ} \mathrm{C}: 150\right.$ 回, $125^{\circ} \mathrm{C}: 30$ 回)、(3)長期試験試験完了後に、部分放電試験お よび $\tan \delta$ 試験も実施し、線路全体としての健全 性確認も行った。

表6 試験条件

Table 6. Test Condition

\begin{tabular}{|c|l|}
\hline Applied voltage & $\mathrm{AC} 77 \mathrm{kV}\left(=\mathrm{U} 0^{*} \sqrt{3}\right)$ \\
\hline Duration & 1 year \\
\hline & $=105^{\circ} \mathrm{C} 8 \mathrm{~h} \mathrm{ON} / 16 \mathrm{~h}$ OFF $\quad 180$ cycles \\
Temperature & $\left(105^{\circ} \mathrm{C} 2\right.$-hour maintenance $)$ \\
& $=125^{\circ} \mathrm{C} 8 \mathrm{~h} \mathrm{ON} / 16 \mathrm{~h}$ OFF $\quad 30$ cycles \\
\hline
\end{tabular}

結果、 1 年間にわたる長期課通電試験期間を 通じて、ケーブルおよびS P J は、絶縁破壊を 生じることなく、試験を完了することができた。 また、前述の通り本試験期間を通じて実施した 部分放電試験および $\tan \delta$ 試験では良好な結果 が得られ、線路としての劣化も無いことを確認 した。

さらに、長期試験後に実施した残存試験にお いて、ケーブル並びにS P J の絶縁破壊性能は、 表7に示す通り、初期性能と同等の良好なもので あった。

以上の結果から、今回開発した $77 \mathrm{kV}$ 級ケーブ ル並びにS P J は而熱用として実用上十分な初期 および長期性能を有していることが確認された。

表7 77kV 級ケーブル並びにSP J の 初期性能試験および残存性能試験結果

Table. 7. Initial and Residual electric breakdown test results of $77 \mathrm{kV}$ cable and SPJ

\begin{tabular}{|c|c|c|c|c|}
\hline \multirow{2}{*}{} & \multicolumn{2}{|c|}{$\begin{array}{c}\text { Initial } \\
\text { performance test }\end{array}$} & \multicolumn{2}{c|}{$\begin{array}{c}\text { Residual } \\
\text { performance test }\end{array}$} \\
\cline { 2 - 5 } & A C & Imp & A C & Imp \\
\hline Cable & $425 \mathrm{kV}$ & $-1040 \mathrm{kV}$ & $475 \mathrm{kV}$ & $-1040 \mathrm{kV}$ \\
\hline S P J & $320 \mathrm{kV}$ & $-920 \mathrm{kV}$ & No Data & $\begin{array}{c}-860 \sim \\
-920 \mathrm{kV}\end{array}$ \\
\hline
\end{tabular}

※Conductor Temperature : $105^{\circ} \mathrm{C}$

\section{7.まとめ}

既設管路の有効利用の一方策として、常時許 容温度を $105^{\circ} \mathrm{C}$ とることを目標として、耐熱 $\mathrm{C}$ Vケーブル並びに接続部の開発を実施した。 本研究で得られた成果は次の通りである。
(1) 現行CVケーブル用絶縁材料よりも高い融 点を有する、耐熱 C V ケーブル用絶縁材料 を開発した。

(2) 開発した絶縁材料は、実用上十分な熱老化 特性と熱機械特性を有している。

(3) 開発した絶縁材料並びに半導電性材料、シ 一ス材料を用いた、モデルケーブル並びに $77 \mathrm{kV}$ 級プロトタイプケーブルを試作し、常 時許容温度 $105^{\circ} \mathrm{C}$ 実運用に十分な、初期性 能と長期性能を有していることを確認し た。

(4) 現行 S P J に低熱抵抗防水コンパウンドを 適用することにより、S P J 部温度上昇を 低减させることが可能であり、耐熱 C V ケ ーブル用接続箱として使用可能であること を確認した。

(6) 絶縁厚 $11 \mathrm{~mm}$ で試作した $77 \mathrm{kV}$ 耐熱 $\mathrm{C} \mathrm{V}$ ケー ブル並びにS P Jについて 1 年にわたる長 期課通電試験を行い、実用 30 年相当以上の 寿命を確認した。また、長期課通電試験後 の残存性能試験においてケーブル、接続箱 の各試料とも初期性能とほぼ同等の性能を 保持していることが確認された。

以上のことから、今回開発した耐熱 C Vケー ブルならびに接続部は、77kV 級線路への適用に 十分耐えうることが検証できた。

\section{参 考 文 献}

(1) S. Nakagawa, Y. Nakanishi, S. Katakai, Y. Murata, M. Kanaoka, "Breakdown Characteristics of XLPE Cable Insulation at High Temperature", 8th International Symposium of High Voltage Engineering, Paper No. 23.04, 1993

(2) S. Nakagawa, Y. Matsuda, H. Yamada: "Study of high temperature characteristics for XLPE cables (Part1)", Proceedings of the Thirteenth Annual Conference of Power \& Energy Society, IEE of Japan, No.353(2002)

中川、松田、山田：「C Vケーブル高温特性の検 討 (その1) 、、平成 14 年電気学会電力. . ルギー部門大会、No.353(2002) 
(3) M. Nakade, T. Matsui, H. Tanaka, K. Takahashi, S. Katakai, S. Miyake, "Electrical Characteristics of an XLPE Cable under High Temperature", T. IEE Japan, Vol.121-B, No.1, 109, 2001 (in Japanese) 中出、松井、田中、高橋、片貝、三宅 : 「C V r ーブルの高温運転電気特性」、電学論 B、1 21 巻 1 号、109 (2001)

(4) M. Nakade, T. Matsui, "Oxidative Degradation Characteristics of a Tape Lapped Cable Joint", T. IEE Japan, Vol.121-B, No.11, 1524, 2001 (in Japanese)

中出、松井 :「テープ巻き絶縁形ケーブル接続部 の酸化劣化特性小、電学論 B、 121 巻 11 号、 1524 (2001)

(5) G. Okamoto, N. Yoshikawa, Y. Inoue, S. Narisada, K. Fudamoto, M. Yamashita and A. Konashi, "Development of Self-Pressurized Joint for $66-\mathrm{kV}$ to 275-kV XLPE Cables", SEI TECHNICAL REVIEW, No.51, January2001

(6) S. Nakagawa, T. Yamazaki, K. Watanabe, S. Katakai, M. Kanaoka, Y. Kamei: "Investigation of Crosslinked Polyethylene with High Melting Point and Its Application to Power Cable Insulation", Proceedings of the Seventh Annual Conference of Power \& Energy Society, IEE of Japan, No.40(1996) 中川、山崎、渡辺、片貝、金岡、亀井 : 「高融点 架橋ポリエチレンケーブルの開発」、平成 8 年電 気学会電力・エネルギー部門大会、No.40(1996)

(7) S. Nakagawa, T. Yamazaki, Y. Murata, T. Gorai, N. Kobayashi: "Fundamental Researches of Heat-resistant Materials for XLPE Cable and Accessory", 1998 National Convention Record I.E.E.Japan, No.349(1998)

中川、山崎、村田、五来、小林 : 「CV ケーブル および付属品の耐熱性向上基礎研究」、平成 10 年電気学会全国大会、No.349（1998）

(8) L. Williams, R. E. Landel, J. D. Ferry, J. AM. Chem. Soc., 77, 3701(1955)

(9) 例えば、村上謙吉編 : 「高分子の化学レオロジ 一」、朝倉書店 (1968)

(10) (社)電気協同研究会：「CVケーブルおよび接続 部の高電圧試験法」、電気協同研究、第51巻第 1 号、(1995)

（2004年6月28日受理）

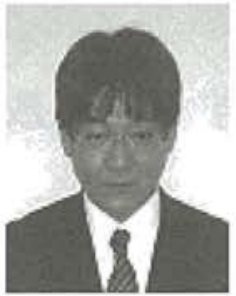

山田浩之（会員）

1973年6月4日生まれ。1994年3月近 畿大学熊野工業高等専門学校電気 工学科卒業。同年4月関西電力株式 会社入社。現在、同社電力技術研 究所勤務。主として、地中送電関係の研究に従事。 電気学会会員。

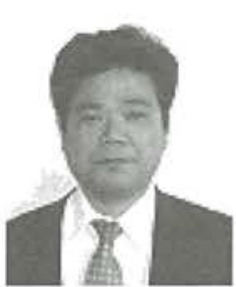

三 宅 孝士郎 (会員)

1960年8月 13 日生まれ。1984年3月 大阪大学工学部電気工学科卒業。 同年4月関西電力株式会社入社。現 在、同社電力技術研究所勤務。主 として、CVケーブルの劣化診断についての研究に 従事。

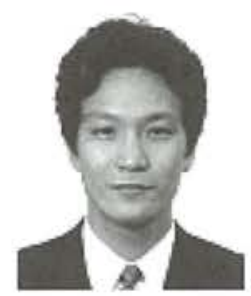

\section{村 田 義 直（会員）}

1968年4月26日生まれ。1992年3月 東京理科大学理工学部物理学科卒 業。同年 4 月日立電線株式会社入 社。2001年10月より株式会社ジェ イ・パワーシステムズ、研究開発センター勤務。主と して、電力ケーブルの研究開発に従事。電気学会会員。

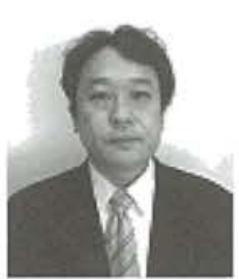

岸幸 治（会員）

1965年8月1日生まれ。1990年3月東 京農工大学工学研究科電気工学専 攻修士課程終了。同年4月住友電気 工業株式会社入社。現在、株式会 社ジェイ・パワーシステムズ、研究開発センター勤 務。主として、電力ケーブルの研究に従事。電気学 会会員。

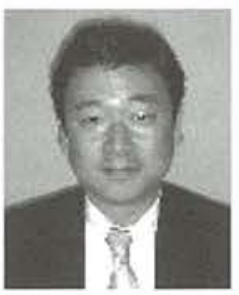

渡辺傑 (会員) 1962年3月24日生まれ。1987年3月 名古屋大学大学院工学研究科結晶 材料工学専攻修士課程終了。同年 4 月住友電気工業株式会社入社。 現在、株式会社ジェイ・パワーシステムズ、電力事業 部技術部勤務。主として、電力ケーブルの開発・設 計に従事。電気学会会員。 